\title{
AUG 01997
}

OSTI

OAK RIDGE NATIONAL LABORATORY

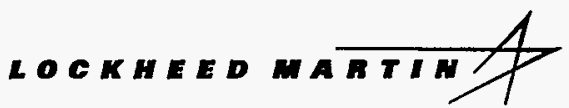

Database Dictionary for the Results of Groundwater Tracer Tests Using Tritiated Water, Conducted at the Oak Ridge National Laboratory
B. K. Thompson' and D
D. Huff ${ }^{2}$

Department of Civil Engineering, The University of Tennessee, Knoxville, TN 37996

${ }^{2}$ Environmental Sciences Division, Oak Ridge National Laboratory, Oak Ridge, TN 37831-6400

Date Published: May 1997

Prepared by the Environmental Sciences Division Oak Ridge National Laboratory ESD Publication No. 4509

\section{MASTER}

\section{DISTRIBUTION OF THS DOOUMENT IS UNLIMITED}

Oak Ridge National Laboratory Oak Ridge, Tennessee 37831-6400 managed by Lockheed Martin Energy Research Corp. for the 


\section{DISCLAIMER}

This report was prepared as an account of work sponsored by an agency of the United States Government. Neither the United States Government nor any agency thereof, nor any of their employees, makes any warranty, express or implied, or assumes any legal liability or responsibility for the accuracy, completeness, or usefulness of any information, apparatus, product, or process disclosed, or represents that its use would not infringe privately owned rights. Reference herein to any specific commercial product, process, or service by trade name, trademark, manufacturer, or otherwise does not necessarily constitute or imply its endorsement, recommendation, or favoring by the United States Government or any agency thereof. The views and opinions of authors expressed herein do not necessarily state or refiect those of the United States Government or any agency thereof. 


\section{DISCLAIMER}

Portions of this document may be illegible electronic image products. Images are produced from the best available original document. 
Lockheed Martin Energy Research Groundwater Program Office

DATABASE DICTIONARY FOR THE RESULTS OF GROUNDWATER TRACER TESTS USING TRITIATED WATER, CONDUCTED AT THE OAK RIDGE NATIONAL LABORATORY

B. K. Thompson' and D. D. Huff ${ }^{2}$

${ }^{1}$ Department of Civil Engineering, The University of Tennessee, Knoxville, TN 37996

${ }^{2}$ Environmental Sciences Division, Oak Ridge National Laboratory, Oak Ridge, TN $37831-6400$

Date Published: May 1997

Prepared by the

Environmental Sciences Division

Oak Ridge National Laboratory

ESD Publication No. 4509

OAK RIDGE NATIONAL LABORATORY

Oak Ridge, Tennessee 37831-6400 managed by

LOCKHEED MARTIN ENERGY RESEARCH CORP.

for the

U.S. DEPARTMENT OF ENERGY

under contract DE-AC05-960R22464 



\section{CONTENTS}

Page

LIST OF TABLES $\ldots \ldots \ldots \ldots \ldots \ldots \ldots \ldots \ldots \ldots \ldots \ldots \ldots \ldots \ldots \ldots \ldots$

ACRONYMS AND ABBREVIATIONS $\ldots \ldots \ldots \ldots \ldots \ldots \ldots \ldots \ldots \ldots \ldots \ldots \ldots \ldots$ vii

EXECUTIVE SUMMARY $\ldots \ldots \ldots \ldots \ldots \ldots \ldots \ldots \ldots \ldots \ldots \ldots \ldots \ldots \ldots \ldots \ldots$

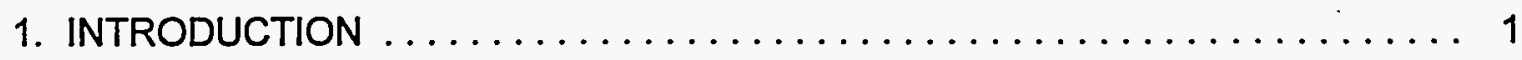

2. STRUCTURE OF THE DATABASE $\ldots \ldots \ldots \ldots \ldots \ldots \ldots \ldots \ldots \ldots \ldots \ldots \ldots \ldots \ldots \ldots$

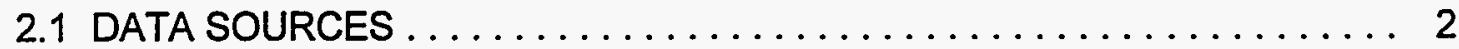

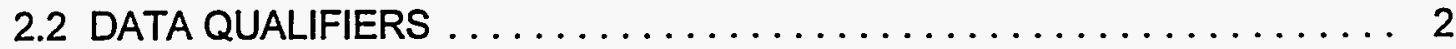

2.3 KEY VARIABLES $\ldots \ldots \ldots \ldots \ldots \ldots \ldots \ldots \ldots \ldots \ldots \ldots \ldots \ldots \ldots \ldots \ldots \ldots$

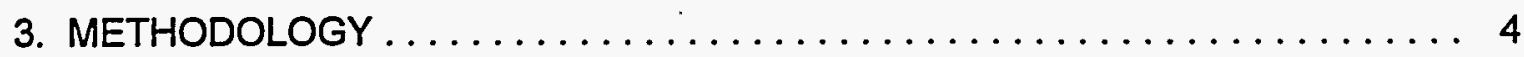

3.1 PRECIPITATION DATA METHODOLOGY $\ldots \ldots \ldots \ldots \ldots \ldots \ldots \ldots, 4$

3.2 TRITIUM DATA METHODOLOGY $\ldots \ldots \ldots \ldots \ldots \ldots \ldots \ldots \ldots, 4$

3.3 WATER-LEVEL DATA METHODOLOGY $\ldots \ldots \ldots \ldots \ldots \ldots \ldots \ldots, 4$

3.4 WELL DATA METHODOLOGY $\ldots \ldots \ldots \ldots \ldots \ldots \ldots \ldots \ldots \ldots \ldots$

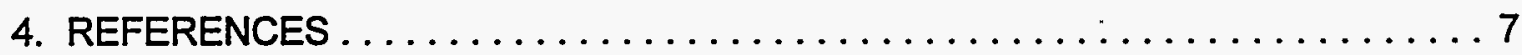

APPENDIX A. FILE DESCRIPTIONS $\ldots \ldots \ldots \ldots \ldots \ldots \ldots \ldots \ldots \ldots$ 


\section{LIST OF TABLES}

Page

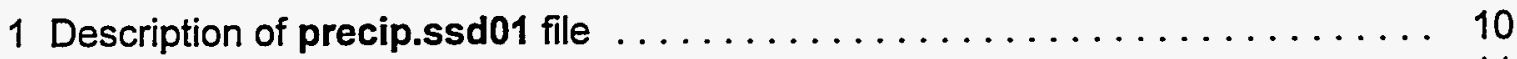

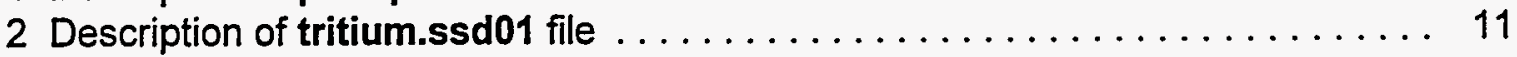

3 Description of watelev.ssd01 file $\ldots \ldots \ldots \ldots \ldots \ldots \ldots \ldots \ldots \ldots \ldots, 12$

4 Description of well.ssd01 file $\ldots \ldots \ldots \ldots \ldots \ldots \ldots \ldots \ldots \ldots \ldots \ldots$ 


\section{ACRONYMS AND ABBREVIATIONS}

$\begin{array}{ll}\text { ASCll } & \text { American Standard Code for Information Interchange } \\ \mathrm{DOE} & \text { U.S. Department of Energy } \\ \mathrm{dpm} / \mathrm{ml} & \text { disintegrations per minute per milliliter } \\ \mathrm{ft} / \mathrm{d} & \text { feet per day } \\ \mathrm{ft} / \mathrm{d} & \text { feet squared per day } \\ \text { ORNL } & \text { Oak Ridge National Laboratory } \\ \mathrm{SAS} & \text { Statistical Analysis System, registered trademark or the SAS } \\ & \text { Institute, Inc., Cary, North Carolina } \\ \text { USGS } & \text { United States Geologic Survey } \\ \text { YY-MM-DD } & \text { date: year year-month month-day day }\end{array}$





\section{EXECUTIVE SUMMARY}

In 1977, the United States Geological Survey (USGS) conducted two tracer tests at the Oak Ridge National Laboratory (ORNL) using tritiated water to study the relative importance of bedding-plane openings on shallow groundwater flow. Through a cooperative agreement between the USGS and the U.S. Department of Energy (DOE), the data were made available to researchers at the Oak Ridge National Laboratory (ORNL), who organized the data into a data management format. The results of these groundwater tracer tests have been compiled into a collection of four SAS data sets. This report documents these SAS data sets, including their structure, methodology, and content.

The SAS data sets include information on precipitation, tritium, water levels, and well construction for wells at or near ORNL radioactive waste burial grounds 4,5 , and 6 . The precipitation data set (precip.ssd01) contains precipitation dates, burial ground identifiers, precipitation amounts, and measurement qualifiers. The tritium data set (tritium.ssd01) contains well sampling dates, tritium activities, and laboratory and quality control qualifiers. The water level data set (watelev.ssd01) contains well names, water measurement dates, water surface depths, and estimated water level elevations. The well data set (well.ssd01) contains well names and locations, water column heights, apparent transmissivities and hydraulic conductivities, heights of well casings above the land surface, top-of-casing elevations, top- and bottom-of-sampleinterval elevations, and land surface elevations. In each SAS data set, one or more of the variables were designated as key variables; these variables allow the records to be identified uniquely and make possible the merging of data from different data sets to form secondary files to meet specialized needs.

Four ASCII files [OR.PRECIP (precipitation data), TABLE-41 (tritium data), ORNL.SUBF (water level data), and OR.HYD.TESTS (well data)] supplied by USGS provided the basis for the SAS data sets. The information in these files was supplemented by information from D. A. Webster at USGS and D. D. Huff at ORNL. The ASCIl files are archived on gwater.esd.ornl.gov in the directory /data/bhy/usgs, and the SAS data sets are stored on the same workstation in the directory /lib1/bhy/usgs.

An interpretive report that discusses the results of the tracer tests is available as Water Resources Investigation Report 95-4182, prepared by the USGS in cooperation with the DOE (Webster, D. A., 1996). Questions concerning the data collection process should be directed to the USGS District Office in Nashville, Tennessee. 


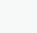




\section{INTRODUCTION}

In 1977, the United States Geological Survey (USGS) initiated two tracer tests to study the relative importance of bedding-plane openings on shallow groundwater flow. The data collected during those tests have remained unpublished. Recently, however, scientists have recognized the value of these data in aiding understanding of the importance of the diffusion process on transport of contaminants in groundwater. Through a cooperative agreement between the USGS and the U.S. Department of Energy (DOE), the data were made available to researchers at the Oak Ridge National Laboratory (ORNL), who organized the data into a data management format.

The results of groundwater tracer tests using tritiated water, conducted at the Oak Ridge National Laboratory (ORNL), have been compiled into a collection of four SAS' data sets. The SAS data sets include information on precipitation, tritium, water levels, and well construction at or near burial grounds 4,5 , and 6 . The information included in the SAS data sets came from four ASCll files, personal communications with D. A. Webster at the United States Geological Survey (USGS), and comments from D. D. Huff at ORNL. The ASCll files are archived on gwater.esd.ornl.gov in the directory /data/bhy/usgs, and the SAS data sets are stored on the same workstation in the directory /lib1/bhy/usgs. This report documents the four SAS data sets, including their structure, methodology, and content.

An interpretive report that discusses the results of the tracer tests is available as Water Resources Investigation Report 95-4182, prepared by the USGS in cooperation with the DOE (Webster, D. A., 1996) ${ }^{2}$. Questions concerning the data collection process should be directed to the USGS District Office in Nashville, Tennessee.

\footnotetext{
1SAS is the registered trademark of SAS Institute, Inc., Cary, North Carolina.

${ }^{2}$ Copies of the report may be purchased from:

US Geological Survey

Branch of Information Services

Box 25286

Denver, CO 80225-0286
} 


\section{STRUCTURE OF THE DATABASE}

The groundwater tracer-test data files are stored in SAS. The database contains four files: precipitation (precip.ssd01), tritium (tritium.ssd01), water levels (watelev.ssd01), and well information (well.ssd01). Appendix A describes the structure of each database file, including the variable name, the type of variable (character, date, or numeric), the width of each variable, and a complete description of each variable, including units and abbreviations.

\subsection{DATA SOURCES}

The information used to create precip.ssd01 came from the ASCll file called OR.PRECIP. OR.PRECIP contains the date the precipitation occurred, the amount of precipitation at burial grounds 5 and 6 , and precipitation qualifiers.

The information used to create tritium.ssd01 came from the ASCll file called TABLE-41. TABLE-41 contains the date each sample was taken, the tritium concentration at each well, and a laboratory qualifier. $X$ qualifiers were added to tritium.ssd01 on the basis of comments by D. D. Huff at ORNL (see Sect. 2.2 for details).

The information used to create watelev.ssd01 came from the ASCII file called ORNL.SUBF. ORNL.SUBF contains the well names, the date each measurement was taken, and each well's depth to water from land surface. The elevations of the water levels were calculated from estimated top-of-casing elevations (see Sect. 3.4 for details).

The information used to create well.ssd01 came from the ASCII file called OR.HYD.TESTS and from D. A. Webster. OR.HYD.TESTS contains the height of the water column in each well, the apparent transmissivity, the apparent hydraulic conductivity, and the well name. D. A. Webster supplied the top-of-casing elevations, the eastings and northings, the distances the casings extend above the land surface, and the well names. Elevations of the bottom and top of the sample interval, the land surface, and the top of casing were calculated for this data set (see Sect. 3.4 for details).

\subsection{DATA QUALIFIERS}

The precipitation qualifiers are either a $\mathrm{C}$ or an $\mathrm{M}$. C indicates clock failure: precipitation occurred during the period indicated, but date of precipitation is indefinite. $M$ indicates a gage malfunction: the precipitation data is incomplete or missing. The laboratory qualifier in the tritium data set is $<$, which indicates that the concentration of tritium is equal to or less than the reported value. $X$ qualifiers were added to observations in this data set on the basis of comments from D. D. Huff at ORNL. An X indicates the sample was cross-contaminated in the field or the laboratory. 


\subsection{KEY VARIABLES}

The database files contain variables, called key variables, that allow the records to be identified uniquely. The key variables also make possible the merging of . information from different data sets to form secondary files to meet specialized needs. The key variables for precip.ssd01 are (1) the burial ground where the precipitation was measured (BURIAL_G) and (2) the date the precipitation was recorded (DATE). The key variables for tritium.ssd01 are (1) the date the sample was taken (DATE); (2) the time of sampling relative to the time of tritium injection (INITIAL), i.e., whether prior to injection (INITIAL = YES) or after injection (INITIAL = NO); and (3) the well name (WELL). The key variable INITIAL was necessary because wells 4-11 and 6-7 were sampled twice on the day the tracers were injected-once before injection and once after. All other records in tritium.ssd01 can be uniquely identified by the DATE and WELL variables. The key variables for watelev.ssd01 are (1) the date the water-level measurement was taken (DATE) and (2) the well name (WELL). The key variable for well.ssd01 is the well name (WELL). 


\section{METHODOLOGY}

The files OR.PRECIP, TABLE-41, ORNL.SUBF, and OR.HYD.TESTS were modified in a text editor before they were imported into SAS. This editing included column alignment, removal of descriptive text, removal of blank spaces when numbers were reported in scientific notation, and replacement of a double hyphen (--) by a period (.). The double hyphen indicated that no sample was collected in the original data; a period is the SAS character for a missing numeric value. The ASCll files were imported into SAS, after which the SAS file structures were modified to fit the database structures defined in Appendix A. X qualifiers, which were not part of the original data, were added to some records in the tritium.ssd01 file (see Sect. 2.2).

Some of the data had to be keyed in by hand. These included a single record in tritium.ssd01 and several records in well.ssd01. Because well.ssd01 has only 16 records, double checking the data entry was not difficult. All date variables are displayed by a two-digit year, a two-digit month, and a two-digit day: YY-MM-DD.

\subsection{PRECIPITATION DATA METHODOLOGY}

The structure of precip.ssd01 was modified from the original data file, TABLE41. The original file had separate columns for burial grounds 5 and 6 . Data for each burial ground were imported into SAS separately and then merged into one data set, precip.ssd01. In precip.ssd01 the variables include (1) the date the precipitation was measured (DATE), (2) the precipitation amount (PRECIP), (3) the precipitation qualifiers (PRECIP_C), and (4) the burial ground where the precipitation was measured (BURIAL_G).

\subsection{TRITIUM DATA METHODOLOGY}

The structure of tritium.ssd01 was modified from the original data file, TABLE41. The original file had separate columns for each well and two groups of data, one for burial ground 4 and one for burial ground 6 . Data for each burial ground were imported into SAS separately, transposed, and then merged into one data set, tritium.ssd01. The restructuring of this file produced some records with missing tritium values. These records were deleted. In tritium.ssd01, the variables include (1) the date the tritium sample was taken (DATE); (2) the time of sampling relative to the time of tritium injection (INITIAL), i.e., whether prior to injection (INITIAL = YES) or after injection (INITIAL = NO); (3) the tritium activity (TRIT); (4) the tritium-activity qualifiers (TRIT_C); and (5) the well from which the tritium sample was taken (WELL).

\subsection{WATER-LEVEL DATA METHODOLOGY}

Although the structure of watelev.ssd01 was not modified from that of the original data file, ORNL.SUBF, the well names were converted to the same format found 
in the other data files (e.g., the well name RN:M-6-TR-5 ORNL was changed to 6-5), and a calculated variable was added for the water-level elevations (ELEV_WAT).

ELEV_WAT was calculated [see Eq. (1)] in a SAS data step by subtracting the depth to water (WAT_DEP) from the calculated land-surface elevation (ELEV_SUR) [see Eq. (4)] in well.ssd01.

$$
\text { ELEV_WAT }=\text { ELEV_SUR }- \text { WAT_DEP . }
$$

In addition, watelev.ssd01 contains a variable for the date that the water elevations were measured (DATE) and a variable for the well where the water-elevation measurements were taken (WELL).

\subsection{WELL DATA METHODOLOGY}

Several tables (in hard copy only), several ASCll files, and an original data file (OR.HYD.TESTS) were combined to create well.ssd01. In well.ssd01 the variables include (1) two variables for the top of casing (CASTOP_B and CASTOP_P), (2) the easting and the northing (EAST and NORTH), (3) the hydraulic conductivity (HYD_COND), (4) the distance the casing extends above the land surface (STICK_UP), (5) the transmissivity (TRANS), (6) the height of the water column in the well shortly after construction minus the depth to the water at the time of the slug test (WATER_HT), (7) the well depth (WEL_DEP), and (8) the name of the well (WELL).

Two top-of-casing variables were created because two surveys for the top of casings were done. One survey, completed by Bernie Frederick, measured the top-ofcasing elevations to a hundredth of a foot. This survey was assigned the variable CASTOP_B. At each site the elevations of the observation wells were calculated in reference to the elevation of the injection well at that site, which was arbitrarily assigned a value of $100.00 \mathrm{ft}$. The other survey was done by the Engineering Division at ORNL. This survey was assigned the variable CASTOP_P. The results of the Engineering survey were reported in feet above mean sea level; however, the results were rounded off to the nearest tenth of a foot.

Because the water levels were measured to the hundredth of a foot and the differences in water level elevations between wells were sometimes small, using the topof-casing elevations measured to the nearest hundredth of a foot (i.e., CASTOP_B) was advantageous. However, because those measurements reflected the relative elevations for the top of the casings and not the elevations above mean sea level, the top-of-casing elevation (ELEV_TOC) was calculated by subtracting $100.00 \mathrm{ft}$. from each injection well's elevation above mean sea level, given by CASTOP_P, then adding the relative elevation given by CASTOP_B for each observation well. In burial ground 4 , the injection well (4-11) has an elevation above mean sea level (CASTOP_P) equal to 843.5. Thus, for burial ground 4,

$$
\text { ELEV_TOC }=843.5-100+\text { CASTOP_B } .
$$


In burial ground 6, the injection well's (6-11) value for CASTOP_P is equal to 774.7. Thus, for burial ground 6 ,

$$
\text { ELEV_TOC }=774.7-100+\text { CASTOP_B. }
$$

The estimated elevation given by ELEV_TOC was used to calculate (1) the landsurface elevation (ELEV_SUR), (2) the elevation of the bottom of the sample interval (ELEV_BOT), and (3) the elevation of the top of the sample interval (ELEV_TOP).

ELEV_SUR was calculated by subtracting the distance the casing extends above the land surface (STICK_UP) from the calculated top-of-casing elevation (ELEV_TOC):

$$
\text { ELEV_SUR }=\text { ELEV_TOC }- \text { STICK_UP } \text {. }
$$

ELEV_BOT is the bottom of the open interval for wells in burial ground 4 and the bottom of the screened interval for wells in burial ground 6 at the time of construction. Some sloughing of uncased borehole walls has probably occurred since then. ELEV_BOT was calculated by subtracting the well depth (WEL_DEP) from the caiculated land-surface elevation (ELEV_SUR) [see Eq. (4)]:

$$
\text { ELEV_BOT }=\text { ELEV_SUR }- \text { WEL_DEP . }
$$

- ELEV_TOP is the top of the open interval for wells in burial ground 4 and the top of the screened interval for wells in burial ground 6 . In burial ground 4, ELEV_TOP was calculated by subtracting the length of the casing hole $(5 \mathrm{ft})$ from ELEV_SUR:

$$
\text { ELEV_TOP }=E L E V \_S U R-5 \text {. }
$$

For all wells in burial ground 6 except well $6-11$ (where the length of the screen was 5 $\mathrm{ft})$, ELEV_TOP was calculated by adding the length of the screen (10 ft) to ELEV_BOT:

$$
\text { ELEV_TOP }=\text { ELEV_BOT }+10 \text {. }
$$

For well 6-11,

$$
E L E V \_T O P=E L E V \_B O T+5
$$




\section{REFERENCES}

Webster, D. A., 1996. Results of Ground-Water Tracing Tests Using Tritiated Water at Oak Ridge National Laboratory, Tennessee, US Geological Survey WaterResources Investigations Report 95-4182, Nashville, Tennessee, 50p. 
APPENDIX A. FILE DESCRIPTIONS 


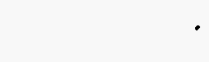


Table 1 Description of precip.ssd01 file

\begin{tabular}{|c|c|c|c|}
\hline $\begin{array}{l}\text { Variable } \\
\text { name }\end{array}$ & Type & Width & Description \\
\hline$\overline{\text { BURIAL_G }}$ & Character & $\overline{1}$ & $\begin{array}{l}\text { Burial ground where precipitation } \\
\text { measurement was taken (key) }\end{array}$ \\
\hline DATE & Date & 8 & $\begin{array}{l}\text { Date when precipitation measurement was } \\
\text { taken (key) }\end{array}$ \\
\hline PRECIP & Numeric & 8 & Precipitation (in.) \\
\hline PRECIP_C & Character & 2 & $\begin{array}{l}\text { Precipitation qualifier } \\
\qquad \begin{array}{l}C=\text { clock failure } \\
M=\text { gage malfunction (record for } \\
\text { date is incomplete or missing) }\end{array}\end{array}$ \\
\hline
\end{tabular}


Table 2 Description of tritium.ssd01 file

\begin{tabular}{llll}
\hline $\begin{array}{l}\text { Variable } \\
\text { name }\end{array}$ & Type & Width & Description \\
\hline DATE & Date & 8 & Date when sample was taken (key) \\
INITIAL & Character & 10 & $\begin{array}{l}\text { Time of sampling relative to the time of } \\
\text { tritium injection } \\
\text { YES = sample taken prior to } \\
\text { injection (i.e., initially) } \\
\text { NO = sample taken after injection } \\
\text { (i.e., not initially) }\end{array}$ \\
TRIT & Numeric & 8 & $\begin{array}{c}\text { Tritium activity (dpm/ml) } \\
\text { TRIT_C }\end{array}$ \\
Character & 2 & $\begin{array}{c}\text { Qualifier for tritium activity } \\
<=\text { concentration of tritium is equal to } \\
\text { or less than the reported value } \\
X=\text { the sample was cross } \\
\text { contaminated in the field or the } \\
\text { laboratory }\end{array}$ \\
WELL & Character & 8 & Well name (key) \\
\hline Disintegrations per minute per milliliter of sample
\end{tabular}


Table 3 Description of watelev.ssd01 file

\begin{tabular}{llll}
\hline $\begin{array}{l}\text { Variable } \\
\text { name }\end{array}$ & Type & Width & Description \\
\hline DATE & Date & 8 & $\begin{array}{l}\text { Date when the water level measurement } \\
\text { was taken (key) }\end{array}$ \\
ELEV_WAT & Numeric & 8 & $\begin{array}{l}\text { Estimated water-level elevation (ft above } \\
\text { mean sea level) }\end{array}$ \\
WAT_DEP & Numeric & 8 & $\begin{array}{l}\text { Depth to water (ft below land surface) } \\
\text { WELL }\end{array}$ \\
\hline
\end{tabular}


Table 4 Description of well.ssd01 file

\begin{tabular}{|c|c|c|c|}
\hline $\begin{array}{l}\text { Variable } \\
\text { name }\end{array}$ & Type & Width & Description \\
\hline$\overline{\text { CASTOP_B }}$ & Numeric & 8 & $\begin{array}{l}\text { Top-of-casing elevations (ft), provided by } \\
\text { Bernie Frederick. The elevation of each } \\
\text { observation well was referenced to that of } \\
\text { the nearest injection well; each injection } \\
\text { well was arbitrarily assigned an elevation of } \\
100.00 \mathrm{ft}\end{array}$ \\
\hline CASTOP_P & Numeric & 8 & $\begin{array}{l}\text { Top-of-casing elevations (ft above mean } \\
\text { sea level), provided by the Engineering } \\
\text { Division at ORNLa }\end{array}$ \\
\hline EAST & Numeric & 8 & $\begin{array}{l}\text { East coordinate (ORNL coordinate system, } \\
\text { ft) }\end{array}$ \\
\hline ELEV_BOT & Numeric & 8 & $\begin{array}{l}\text { Estimated bottom-of-sample-interval } \\
\text { elevation (ft above mean sea level) }\end{array}$ \\
\hline ELEV_SUR & Numeric & 8 & $\begin{array}{l}\text { Estimated land surface elevation (ft above } \\
\text { mean sea level) }\end{array}$ \\
\hline ELEV_TOC & Numeric & 8 & $\begin{array}{l}\text { Estimated top-of-casing elevation (ft above } \\
\text { mean sea level) }\end{array}$ \\
\hline ELEV_TOP & Numeric & 8 & $\begin{array}{l}\text { Estimated top-of-sample-interval elevation } \\
\text { (ft above mean sea level) }\end{array}$ \\
\hline HYD_COND & Numeric & 8 & Apparent hydraulic conductivity ( $\mathrm{ft} / \mathrm{d}$ ) \\
\hline NORTH & Numeric & 8 & $\begin{array}{l}\text { North coordinate (ORNL coordinate system, } \\
\mathrm{ft} \text { ) }\end{array}$ \\
\hline STICK_UP & Numeric & 8 & $\begin{array}{l}\text { Distance the top of the well casing extends } \\
\text { above land surface (ft) }\end{array}$ \\
\hline TRANS & Numeric & 8 & Apparent transmissivity $\left(\mathrm{ft}^{2} / \mathrm{d}\right)$ \\
\hline WATER_HT & Numeric & 8 & $\begin{array}{l}\text { Height of water column in the well; value } \\
\text { equals well depth shortly after construction } \\
\text { minus the depth to water at the time of the } \\
\text { slug test }\end{array}$ \\
\hline WELDEP & Numeric & 8 & $\begin{array}{l}\text { Completed well depth below land surface } \\
\text { (ft) }\end{array}$ \\
\hline WELL & Character & 8 & Well name (key) \\
\hline
\end{tabular}


1. T. L. Cothron

2. J. H. Cushman

3. N. H. Cutshall

4. A. F. Diefendorf

5. T. O. Early

6. D. E. Fowler

7. G. -P. Gwo

8. C.S. Haase

9. R. D. Hatcher, Jr.

10. S. G. Hildebrand

11-15. D. D. Huff

16. G. K. Jacobs

17. W. K. Jago

18. P. M. Jardine

19. S. B. Jones

20. P. Kancircuk

21. R. H. Ketelle

22. A. J. Kuhaida

23. R. R. Lee
24. J. M. Loar

25. J. F. McCarthy

26. L. W. McMahon

27. G. R. Moline

28. T. E. Myrick

29. D. E. Reichle

30. C. T. Rightmire

31. T. H. Row

32. S. D. Shriner

33. M. F. Tardiff

34. L. E. Toran

35. J. R. Trabalka

36. D. B. Watson

37. T. F. Zondlo

38. Central Research Library

39-53. ESD Library

54-55. Laboratory Records Department

56. Laboratory Records, ORNL-RC

57. Y-12 Technical Library

\section{EXTERNAL DISTRIBUTION}

59. Richard Arnseth, SAIC, 301 Laboratory Rd., Oak Ridge, TN 37830

60. G. W. Bodenstein, USDOE-OR Federal Building, Oak Ridge, TN 37830

61. M. Broido, Acting Director, Environmental Sciences Division, Department of Energy, 19901 Germantown Road, Germantown, Maryland 20874

62. Paul Craig, Environmental Consulting Engineers, P. O. Box 22668, Knoxville, TN 37933

63. E. G. Cumesty, ORNL Site Manager, Department of Energy, Oak Ridge National Laboratory, P.O. Box 2008, Oak Ridge, TN 37831-6269

64. Director, Center for Management, Utilization, and Protection of Water Resources, Tennessee Technological University, P. O. Box.5082, Cookeville, TN 38505

65. F. A. Donath, Director, Institute for Environmental Education, Geological Society of America, 1006 Las Posas, San Clemente, California 92673

66. . D. W. Freckman, Director, College of Natural Resources, 1001 Natural Resources Buildings, Colorado State University, Fort Collins, Colorado 80523

67. Jim Harless, TDEC/DOE Oversight, 761 Emory Valley Road, Oak Ridge, TN 37830

68. P. Hofmann, U.S. Department of Energy, Oak Ridge Operations, 3 Main Street, Oak Ridge, TN 37830

69. G. M. Hornberger, Department of Environmental Sciences, University of Virginia, Chariottesville, VA 22903

70. S. B. Jones, TDEC/DOE Oversight, 761 Emory Valley Rd., Oak Ridge, TN 37830

71. G. Y. Jordy, Office of Program Analysis, Office of Energy Research, ER-30, G-226, US Department of Energy, Washington, DC 20545

72. P. E. Lamoreaus \& Assoc. Inc., P. O. Box 2310, Tuscaloosa, AL 35403

73. Michael C. McCracken, Director, Office of the U.S. Global Change Research Program, Code YS-1, 300 E Street, SW, Washington, DC 20546 
74. L. D. McKay, Department of Geological Sciences, University of Tennessee, Knoxville, TN 37996-1410

75. Manager, CH2M Hill, 599 Oak Ridge Turnpike, Oak Ridge, TN 37830

76. H. C. Mattraw, Jr., US Geological Survey, 810 Broadway, Suite 500, Nashville, TN 37203

77. G. K. Moore, Route 4, Box 927, Waynešboro, TN 38485

78. Ronit Nativ, Department of Soil and Water Sciences, Faculty of Agriculture, Hebrew University of Jerusalem, P. O. Box 12, Rehovot 76100, ISRAEL

79. A. Patrinos, Associate Director, Office of Health and Environmental Research, Department of Energy, G-165, Germantown, Maryland 20874

80. G. D. Reed, Department of Civil Engineering, University of Tennessee, 62 Perkins Hall, Knoxville, TN 37996-2010

81. G. S. Sayler, Professor, 10515 Research Drive, Suite 100, The University of Tennessee, Knoxville, Tennessee 37932-2567

82. J. Smoot, Department of Civil Engineering, University of Tennessee, 62 Perkins Hall, Knoxville, TN 37996-2010

83. D. K. Solomon, 2381 Beacon Drive, Salt Lake City, UT 84108

84. D. A. Stephenson, South Pass Resources, Inc., 8669 East San Alberto Drive, Suite 101, Scottsdale, AZ 85258

85. B. A. Tschantz, Department of Civil Engineering, University of Tennessee, 62 Perkins Hall, Knoxville, TN 37996-2010

86. D. A. Webster, US Geological Survey, 810 Broadway, Suite 500, Nashville, TN 37203

87. F. J. Wobber, Environmental Sciences Division, Office of Health and Environmental Research, Office of Energy Research, ER-74, US Department of Energy, Washington, DC 20585

88-89. S. C. Young, Environmental Consulting Engineers, P. O. Box 22668, Knoxville, TN 37933

90. Office of Assistant Manager for Energy Research and Development, U.S. Department of Energy Oak Ridge Operations, P.O. Box 2001, Oak Ridge, Tennessee 37831-8600

91. (2) Office of Scientific and Technical Information, P.O. Box 62, Oak Ridge, Tennessee 37831 